\title{
Divalent metal ions tune the self-splicing reaction of the yeast mitochondrial group II intron Sc.ai5 $\gamma$
}

\author{
Michèle C. Erat $\cdot$ Roland K. O. Sigel
}

Received: 26 February 2008/ Accepted: 14 May 2008/Published online: 5 June 2008

(C) SBIC 2008

\begin{abstract}
Group II introns are large ribozymes, consisting of six functionally distinct domains that assemble in the presence of $\mathrm{Mg}^{2+}$ to the active structure catalyzing a variety of reactions. The first step of intron splicing is well characterized by a Michaelis-Menten-type cleavage reaction using a two-piece group II intron: the substrate RNA, the $5^{\prime}$-exon covalently linked to domains 1,2 , and 3 , is cleaved upon addition of domain 5 acting as a catalyst. Here we investigate the effect of $\mathrm{Ca}^{2+}, \mathrm{Mn}^{2+}, \mathrm{Ni}^{2+}, \mathrm{Zn}^{2+}$, $\mathrm{Cd}^{2+}, \mathrm{Pb}^{2+}$, and $\left[\mathrm{Co}\left(\mathrm{NH}_{3}\right)_{6}\right]^{3+}$ on the first step of splicing of the Saccharomyces cerevisiae mitochondrial group II intron $S c$.ai5 $\gamma$. We find that this group II intron is very sensitive to the presence of divalent metal ions other than $\mathrm{Mg}^{2+}$. For example, the presence of only $5 \% \mathrm{Ca}^{2+}$ relative to $\mathrm{Mg}^{2+}$ results in a decrease in the maximal turnover rate $k_{\text {cat }}$ by $50 \%$. $\mathrm{Ca}^{2+}$ thereby has a twofold effect: this metal ion interferes initially with folding, but then also competes directly with $\mathrm{Mg}^{2+}$ in the folded state, the latter being indicative of at least one specific $\mathrm{Ca}^{2+}$ binding pocket interfering directly with catalysis. Similar results are obtained with $\mathrm{Mn}^{2+}, \mathrm{Cd}^{2+}$, and $\left[\mathrm{Co}\left(\mathrm{NH}_{3}\right)_{6}\right]^{3+} \cdot \mathrm{Ni}^{2+}$ is a much more powerful inhibitor and the presence of either $\mathrm{Zn}^{2+}$ or $\mathrm{Pb}^{2+}$ leads to rapid degradation of the RNA. These results show a surprising sensitivity of such a large multidomain RNA on trace amounts of cations other than $\mathrm{Mg}^{2+}$ and raises the question of biological relevance at least in the case of $\mathrm{Ca}^{2+}$.
\end{abstract}

M. C. Erat · R. K. O. Sigel ( $\square)$

Institute of Inorganic Chemistry,

University of Zurich,

8057 Zurich, Switzerland

e-mail: roland.sigel@aci.uzh.ch
Keywords Ribozyme - Self splicing - Group II intron · Divalent cations $\cdot$ Metal ion inhibition

\section{Introduction}

Natural ribozymes, i.e., catalytic RNAs, mostly carry out phosphodiester cleavage or phosphoryl transfer reactions [1], but they can potentially be engineered to assume many more functions $[2,3]$. The simplest true ribozyme described to date is the trinucleotide UUU, which cleaves the GAAA tetranucleotide specifically between $\mathrm{G}$ and $\mathrm{A}$ in the presence of $\mathrm{Mn}^{2+}$ [4]. This minimal catalytically active structure provides evidence that even very simple RNAs can direct specific hydrolysis, using metal ions as their cofactor.

No RNA molecule can exhibit its function in the absence of metal ions. Divalent metal ions are crucial to achieve the folded state and are often implicated to also participate directly in catalysis in some way [5]. Among the small ribozymes, a few can also be activated in the presence of molar concentrations of monovalent ions only [6-8]. The smallest among these ribozymes, the hammerhead ribozyme, was identified on the positive strand of the satellite RNA from the tobacco ringspot virus. Like in all ribozymes, $\mathrm{Mg}^{2+}$ is considered to be the natural cofactor, but interestingly the hammerhead ribozyme reaches its highest activity in the presence of $\mathrm{Mn}^{2+}[9] . \mathrm{Co}^{2+}, \mathrm{Ni}^{2+}$, $\mathrm{Zn}^{2+}$, and $\mathrm{Cd}^{2+}$ also lead to higher in vitro cleavage rates than $\mathrm{Mg}^{2+}[9,10]$. Obviously, the hammerhead ribozyme is rather flexible in its usage of divalent metal ions, as is additionally illustrated by its activity in the presence of $\mathrm{Ca}^{2+}, \mathrm{Sr}^{2+}$, and $\mathrm{Ba}^{2+}$. Instead, the hairpin ribozyme that is found on the negative strand of the same virus and displays the same overall mechanism only shows efficient catalysis 
in the presence of $\mathrm{Mg}^{2+}, \mathrm{Ca}^{2+}$, and $\mathrm{Sr}^{2+}$, but not with $\mathrm{Mn}^{2+}$ and $\mathrm{Co}^{2+}[11]$.

From the abovementioned examples it is already clear that ribozymes are very sensitive to the presence of divalent metal ions other than $\mathrm{Mg}^{2+}$. This specific recognition must be based on charge, size, and coordination preferences of these metal ions and has been exploited in recent years by engineering in vitro selected DNAzymes specific to $\mathrm{Mg}^{2+}, \mathrm{Ca}^{2+}, \mathrm{Zn}^{2+}$ or even $\mathrm{Pb}^{2+}[12-16]$. The metal ion specificity can thereby also be switched from $\mathrm{Mg}^{2+}$ to, e.g., $\mathrm{Ca}^{2+}$, as has been shown with the Tetrahymena $[17,18]$ as well as the Azoarcus [19] group I introns, which are usually only active in the presence of either $\mathrm{Mg}^{2+}$ or $\mathrm{Mn}^{2+}$.

Group II introns are the largest naturally occurring ribozymes apart from the ribosome, consisting of six domains projecting from a central wheel (Fig. 1). All group II introns investigated until today require $\mathrm{Mg}^{2+}$ for activity, although the amount needed differs up to a factor of 1,000 depending on the origin of the intron [20-22]. Folding and domain assembly is in all cases induced by the addition of $\mathrm{Mg}^{2+}$. Recent studies showed that in the D135 ribozyme derived from the Saccharomyces cerevisiae group II intron $S c$.ai $5 \gamma$, the $\kappa-\zeta$ region within domain 1 (D1) constitutes the nucleation element for folding at low millimolar $\mathrm{Mg}^{2+}$ concentration, guiding the D1 scaffold to the correct architecture [23, 24]. At higher $\mathrm{Mg}^{2+}$ concentrations, the other domains then subsequently bind to D1, with domain 5 (D5) coming last and completing the catalytic core [25].

Although $\mathrm{Mg}^{2+}$ is believed to be the natural metal ion cofactor of group II introns and to be involved directly in catalysis [26, 27], many other kinds of metal ions have been applied for different purposes: $\mathrm{Mn}^{2+}$ and $\mathrm{Zn}^{2+}$ [28], as well as lanthanide(III) and $\mathrm{Pb}^{2+}$ ions revealed metal ion binding sites $[23,29,30]$, and $\mathrm{Mn}^{2+}, \mathrm{Zn}^{2+}$, and $\mathrm{Cd}^{2+}$ were used in nucleotide analogue interference mapping/suppression (NAIH/NAIS) studies to reveal tertiary contacts as well as to identify coordinating atoms within the catalytic center via thio-rescue experiments [26, 31-34]. It is obvious that all of these ions differ in their intrinsic coordinating properties [35], and their binding pattern might also be influenced differently by changes in the electric permittivity within the folded RNA structure [36]. However, despite their general usage, the effect of these different metal ions on splicing has to the best of our knowledge not yet been quantified. In addition, in the light of the above-described accelerating effect of metal ions other than $\mathrm{Mg}^{2+}$ on the hammerhead function, also the question arises of whether such an effect is also seen in the case of group II introns, and whether there is a possible biological relevance.

Here, we apply a well-characterized bipartite system consisting of the $5^{\prime}$-exon covalently linked to D1 and
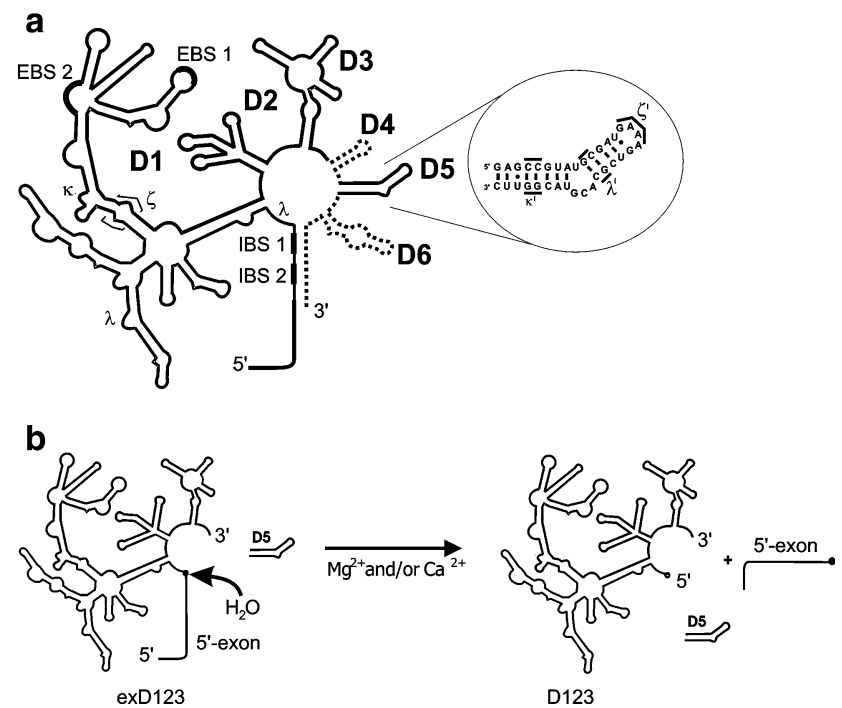

Fig. 1 Schematic representation of a group II intron secondary structure together with the trans-splicing assay used. a The six functionally distinct domains of the group II intron $S c$.ai5 $\gamma$ from the Saccharomyces cerevisiae mitochondrial coxl gene with catalytic domain 5 (D5) enlarged are shown. The three tertiary contacts between domain $1(D I)$ and D5 $\left(\kappa-\kappa^{\prime}, \lambda-\lambda^{\prime}, \zeta-\zeta^{\prime}\right)$ and the exon/intron binding interactions (EBS1/IBS1 and EBS2/IBS2), which are responsible for proper alignment of the splice site in the catalytic core, are indicated. b The single-turnover trans-cleavage assay: the substrate (exD123) consists of the last 293 nucleotides from the $5^{\prime}$-exon, including the intron binding sites IBS1 and IBS2, the $5^{\prime}$-splice site as well as D1 and domains 2 and 3 from the intron $S c$.ai5 $\gamma$ (710 nucleotides). The catalytic D5 flanked by 22 nucleotides was added in trans. A solvent water molecule acts as the nucleophile in the first step of splicing (see also "Materials and methods" and the text). The reaction is induced by addition of $\mathrm{Mg}^{2+}$ ions (or $\mathrm{Mg}^{2+}-$ to- $\mathrm{Ca}^{2+}$ ratios) to yield two products, D123 and the cleaved-off $5^{\prime}$-exon. D5 as a real catalyst is left unchanged during the reaction

domains 2 and 3 (exD123) of Sc.ai5 $\gamma$ as a substrate and D5 added in trans acting as a catalyst (Fig. 1) [37, 38]. This setup has been shown to reliably mimic the first step of splicing and to follow Michaelis-Menten kinetics [37]. We show that in the presence of $90 \mathrm{mM} \mathrm{Mg}^{2+}, 10 \mathrm{mM} \mathrm{Ca}^{2+}$, $\mathrm{Mn}^{2+}, \mathrm{Ni}^{2+}, \mathrm{Zn}^{2+}, \mathrm{Cd}^{2+}, \mathrm{Pb}^{2+}$, or $\left[\mathrm{Co}\left(\mathrm{NH}_{3}\right)_{6}\right]^{3+}$ leads to a substantial inhibition of the first step of splicing, if not even to unspecific degradation of the RNA. For example, the reaction rate is reduced to half by $\mathrm{Ca}^{2+}$ in the presence of 100 -fold excess of $\mathrm{Mg}^{2+}$. This strong inhibition is surprising as $\mathrm{Ca}^{2+}$ is placed below $\mathrm{Mg}^{2+}$ in the periodic table of the elements: $\mathrm{Ca}^{2+}$ shows coordinating properties similar to those of $\mathrm{Mg}^{2+}$, but usually has a lower intrinsic affinity towards nucleic acids [35, 39]. It is interesting to note that mitochondria, in which the coxl gene carrying $S c$.ai5 $\gamma$ resides, act as cellular $\mathrm{Ca}^{2+}$ stores, sequestering and releasing large amounts of $\mathrm{Ca}^{2+}$ depending on the metabolic needs of the cell [40,41], thereby also being involved in controlled cell death [40, 42]. One could thus speculate whether a change in local metal ion concentration 
within a cell (compartment) could be used by nature to regulate and/or switch the activity of a given ribozyme.

\section{Materials and methods}

\section{Materials}

T7 polymerase was prepared using standard procedures [43, 44]. Restriction enzymes for plasmid linearization were purchased from Roche Diagnostics and nucleoside 5'triphosphates were purchased from Amersham Biosciences, now GE Healthcare (Otelfingen, Switzerland), except for UTP, which was obtained from Sigma-Aldrich (Buchs, Switzerland). $\mathrm{MgCl}_{2}$ was utilized as a $1 \mathrm{M}$ solution in $\mathrm{H}_{2} \mathrm{O}$ in ultrapure quality from Fluka (Buchs, Switzerland). $\mathrm{CaCl}_{2}$ solutions were prepared from ultrapure (better than $99.5 \%) \mathrm{CaCl}_{2} \cdot 2 \mathrm{H}_{2} \mathrm{O}$, also from Fluka.

\section{DNA constructs and RNA transcription}

The exD123 RNA (1,003 nucleotides in total, containing 293 nucleotides of the $5^{\prime}$-exon and domains 1,2 and 3 from Sc.ai5 $\gamma$ ) was transcribed from plasmid pJD3'-673 [45] linearized with HindIII. D5-58 (58 nucleotides in total, containing D5 flanked by 22 vector-derived nucleotides) was transcribed from plasmid pJDI5'-75 [45] linearized with HpaII. The shorter D5-36 construct [46] consisting of the 34 nucleotides of D5 plus one terminal $\mathrm{G}-\mathrm{C}$ base pair to improve the transcription yield was transcribed from fully double stranded DNA templates provided by Microsynth (Balgach, Switzerland) [44]. Body-labeled exD123 RNA was transcribed with $\alpha-{ }^{32} \mathrm{P}$-ATP (Amersham Biosciences) in volumes of 20 or $40 \mu \mathrm{L}$, purified by polyacrylamide gel electrophoresis (PAGE), and visualized by autoradiography with a Storm 860 phosphoimager (Amersham Biosciences) [38]. The labeled RNA was eluted by shaking the crushed gel pieces twice in $2 \mathrm{vol}$ of $10 \mathrm{mM}$ 3-( $N$-morpholino)propanesulfonic acid (MOPS), $1 \mathrm{mM}$ EDTA, $250 \mathrm{mM} \mathrm{NaCl}, \mathrm{pH} 6.5$ for $2 \mathrm{~h}$ at $4{ }^{\circ} \mathrm{C}$. The concentration was calculated via the specific activities from the scintillation counts obtained with a 22000CA liquid scintillation analyzer from Canberra Packard. Unlabeled D5-58 RNA was transcribed in a volume of $2 \mathrm{~mL}$ and purified by PAGE, electroeluted with a Biotrap system from Schleicher \& Schuell (Dassel, Germany), and desalted with Centricon centrifugal filter devices (3000 MWCO) from Amicon. The concentrations of the nonradioactive RNA were determined with a Varian Cary 500 Scan UVvis-near-IR spectrophotometer, using the extinction coefficient for D5-58 at $260 \mathrm{~nm}\left(\varepsilon_{260}\right)$ of $6.4 \times 10^{5} \mathrm{M}^{-1} \mathrm{~cm}^{-1}$. The samples were stored in $10 \mathrm{mM}$ MOPS, $\mathrm{pH} 6.5,1 \mu \mathrm{M}$ EDTA at $-20{ }^{\circ} \mathrm{C}$.
Cleavage of exD123 by D5-58 at various $\mathrm{Mg}^{2+}$-to-Ca ${ }^{2+}$ ratios

All trans-cleavage reactions were performed in RNaseDNase-free $0.5-\mathrm{mL}$ reaction tubes in a total volume of 20 or $40 \mu \mathrm{L}$. The reactions were carried out in $40 \mathrm{mM}$ MOPS ( $\mathrm{pH}$ 7.5) and $500 \mathrm{mM} \mathrm{KCl}$. RNA stock solutions were diluted individually and preincubated at $95{ }^{\circ} \mathrm{C}$ for $1 \mathrm{~min}$ to eliminate alternative RNA conformations [38]. The RNAs were left to cool separately to $45{ }^{\circ} \mathrm{C}$. Only then were substrate (exD123) and catalyst (D5) mixed and the reaction was initiated by addition of premixed divalent metal ion stock solutions to a final total concentration of $100 \mathrm{mM} .{ }^{32} \mathrm{P}$ exD123 was provided in a concentration of $1 \mathrm{nM}$ and the concentration of D5 was varied from 0.05 to $6 \mu \mathrm{M}$.

Preliminary experiments were carried out for $30 \mathrm{~min}$ in the presence of $100 \mathrm{mM} \mathrm{MgCl}_{2}$ or $100 \mathrm{mM} \mathrm{CaCl}_{2}$ only, as well as different mixtures of $\mathrm{MgCl}_{2}$ and $\mathrm{CaCl}_{2}$ (80:20; 20:80; 50:50; 100:100; all numbers represent concentrations in millimoles per liter). The reaction in the presence of $100 \mathrm{mM} \mathrm{MgCl} 2$ was performed with D5-58 as well as with the shorter hairpin D5-36 which has been used for the solution structure determination by NMR [46]. No difference between the two D5 constructs was detected. Later experiments were conducted with D5-58 to be able to compare the data directly with previously obtained results from trans-cleavage assays in the presence of $\mathrm{Mg}^{2+}$ alone [38].

To decipher the detailed kinetics of splicing in the presence of $\mathrm{Ca}^{2+}$, trans-cleavage reactions were carried out in the presence of $0-5 \mathrm{mM} \mathrm{Ca}^{2+}$, complemented with $\mathrm{Mg}^{2+}$ to a final divalent metal ion concentration of $100 \mathrm{mM}$. The following mixed-metal stock solutions were prepared prior to the reaction: $1 \mathrm{M} \mathrm{MgCl}_{2}, 990 \mathrm{mM}$ $\mathrm{MgCl}_{2} / 10 \mathrm{mM} \mathrm{CaCl} 2,980 \mathrm{mM} \mathrm{MgCl}_{2} / 20 \mathrm{mM} \mathrm{CaCl}$, $960 \mathrm{mM} \mathrm{MgCl}_{2} / 40 \mathrm{mM} \mathrm{CaCl}$, and $950 \mathrm{mM} \mathrm{MgCl}_{2} /$ $50 \mathrm{mM} \mathrm{CaCl}{ }_{2}$. These stock solutions were diluted 1:10 into the reaction mixture to initiate splicing. Two-microliter aliquots were taken at various times over the whole course of the reaction and immediately quenched with denaturing formamide loading buffer (82\% formamide, $10 \mathrm{mM}$ EDTA, and xyanole cyanide and bromphenol blue as dyes). The samples were kept on ice or frozen before being loaded onto a 5\% polyacrylamide gel for analysis. After electrophoresis, the gels were dried on a Biometra Maxidry geldryer and visualized by autoradiography. The bands were analyzed by Image-Quant 5.2 (Amersham Biosciences).

\section{Single-turnover kinetics}

All experiments used for the kinetic analysis were performed using $1 \mathrm{nM}{ }^{32} \mathrm{P}$-body-labeled exD123 as the 
reaction substrate and an excess of 0.05-6 $\mu \mathrm{M}$ unlabeled "enzyme" D5. To ensure the presence of single-turnover conditions, an experiment with various subsaturating substrate concentrations (1-3 nM) was carried out. As expected for a reaction obeying pseudo-first-order kinetics, no variation in the reaction rate was observed. The reaction was monitored by the evolving product bands and the decrease in substrate bands. To minimize the effects of differential RNA degradation over time, the intensities of the bands were normalized by multiplication of the raw counts of the band with the ratio of the total counts of the three substrate and product bands per lane at $t=0$ and the counts per lane at the time were analyzed. Furthermore, background counts unique to each lane were subtracted from the individual bands to account for random degradation. Because the large exD123 RNA undergoes random hydrolysis over time, only a time up to 80 min was taken into account. The observed rate constants $\left(k_{\text {obs }}\right)$ for each time course were calculated from semilogarithmic plots of the fraction of the decrease in substrate/precursor, i.e., 1 -increase of product versus time $t$, with $m$ being the slope (Eq. 1):

$\ln (\mathrm{fp})=m t+\ln 0.5\left(\frac{m}{k_{\mathrm{obs}}}+1\right)$.

Equation 1 was derived from the basic relationship between $k_{\mathrm{obs}}$ and the half-point of a reaction $\left(\tau_{1 / 2}\right)$ obeying single-turnover conditions

$k_{\mathrm{obs}}=\frac{\ln 2}{\tau_{1 / 2}}$

and the general formula

$y=m x+a$,

where $y \equiv \ln (\mathrm{fp})$ and $x \equiv t$. Thus, at the half-point of the reaction, Eq. 3a reads

$\ln 0.5=m \tau_{1 / 2}+a$.

Combination of Eqs. 2 and $3 \mathrm{~b}$ gives

$\tau_{1 / 2}=\frac{\ln 0.5-a}{m}=\frac{\ln 2}{k_{\mathrm{obs}}}$.

Equation 4 is resolved for $a$ and combined with Eq. 3a to give Eq. 1. Usually, $\tau_{1 / 2}$ is determined first via the slope in semilogarithmic plots of the fraction of precursor versus time and is subsequently used to calculate $k_{\text {obs }}$ via Eq. 2 . Equation 1 has the advantage that it links the experimental data directly to $k_{\text {obs. }}$.

Final $k_{\text {obs }}$ values for each condition were obtained by taking the weighted mean of the individual values with their error limits of at least two experiments. The relative standard error was used for the final $k_{\text {obs }}$ values as it was generally larger than the absolute standard error. Although variations in the observed rate constants were small for experiments from the same exD123 transcription performed within a few days, the kinetic parameters were found to vary up to 1.3 -fold for experiments performed several weeks apart. This phenomenon has been observed before in studies of ribozyme kinetics using entirely different RNA stocks [38, 47, 48].

According to Michaelis-Menten kinetics, a plot of the observed reaction rates versus a range of D5 concentrations could be fitted to Eq. 5 describing a 1:1 bimolecular association curve, yielding $k_{\text {cat }}$, and $K_{\mathrm{D}}$ :

$k_{\mathrm{obs}}=k_{\mathrm{cat}} \frac{\left([\mathrm{exD} 123]+[\mathrm{D} 5]+K_{\mathrm{D}}\right)-\sqrt{\left([\mathrm{exD} 123]+[\mathrm{D} 5]+K_{\mathrm{D}}\right)^{2}-4[\operatorname{exD} 123][\mathrm{D} 5]}}{2[\mathrm{exD} 123]}$,

$k_{\text {obs }}$ is the observed rate constant (per minute), $k_{\text {cat }}$ is the maximum turnover rate (per minute), [exD123] and [D5] are the concentrations of the RNA constructs (millimoles per liter), and $K_{\mathrm{D}}$ is the dissociation constant for dissociation of D5 from exD123 [49-51].

trans-Cleavage reactions with other metal ions

The analogous trans-cleavage assay was performed in the presence of $90 \mathrm{mM} \mathrm{Mg}^{2+}$ and $10 \mathrm{mM} \mathrm{Ca}^{2+}, \mathrm{Mn}^{2+}$, $\mathrm{Ni}^{2+}, \mathrm{Zn}^{2+}, \mathrm{Cd}^{2+}, \mathrm{Pb}^{2+}$, or $\left[\mathrm{Co}\left(\mathrm{NH}_{3}\right)_{6}\right]^{3+}$ as described (vide supra). The substrate ${ }^{32} \mathrm{P}$-exD123 was provided in a concentration of $1 \mathrm{nM}$ and the enzyme D5 at $1 \mu \mathrm{M}$ to reach single turnover reaction conditions [38]. Total aliquots of 3 or $6 \mu \mathrm{L}$ were taken out either at 0,30 , and $90 \mathrm{~min}$ or at $0,20,40$, and 90 or $105 \mathrm{~min}$ and the reaction was quenched by addition of an equal volume of formamide buffer dye. The content of these aliquots was analyzed on a 5\% PAGE gel, run at 30-35 W for 4$5 \mathrm{~h}$, dried and visualized by autoradiography. The bands were analyzed semiquantitatively by Image-Quant 5.2 (Amersham Biosciences).

\section{Results}

The first step of splicing at $100 \mathrm{mM} \mathrm{Mg}^{2+}$

To investigate the effect of different metal ions on the first step of splicing of the group II intron $S c$.ai5 $\gamma$, a cleavage assay has to be applied that shows a uniform reaction and can be well characterized. For this purpose we used an established bipartite trans-splicing assay with the two RNA components exD123 and D5 [38, 52]. exD123 consists of 293 nucleotides of the $5^{\prime}$-exon covalently linked to D1 and domains 2 and 3 and acts as a reaction substrate (Fig. 1). D5 binds to D1, completing the catalytic core, and is unchanged during the reaction because a water molecule 
acts as the nucleophile for the phosphodiester cleavage. The substrate concentration was kept constant at $1 \mathrm{nM}$, whereas D5, being the "enzyme," was added at increasing concentrations of $0.05,0.1,0.5,1,3$, and $6 \mu \mathrm{M}$. Under these conditions, all substrate molecules are bound to the catalyst and the single-turnover reaction follows Michaelis-Menten kinetics.

In the presence of $100 \mathrm{mM} \mathrm{MgCl}$ (and $0.5 \mathrm{M} \mathrm{KCl}$ ), exD123 is almost entirely cleaved within 120 min into its $5^{\prime}$-exon and the intronic fragment D123 (Fig. 1). As observed previously [38], the intronic fragment is subsequently cleaved within D2, yielding secondary cleavage products of 560 and 150 nucleotides in length (Fig. 2). This secondary cleavage is much slower than splicing, and hence the splicing kinetics is not hampered. Combining the two secondary product bands with the D123 band, we find that the kinetic profile is interchangeable with the profile obtained from the $5^{\prime}$-exon evolution and the exact inverse of the disappearance of the substrate. These curves intersect at $50 \%$ of the reaction (Fig. 3).

The reaction rate $k_{\text {obs }}$ for a given D5 concentration was calculated by fitting the experimental data in the linear range of the reaction with Eq. 1 (Fig. 3b, Table 1; see "Materials and methods"). As expected for MichaelisMenten behavior, $k_{\mathrm{obs}}$ increases with higher D5 concentration, approaching a maximal turnover rate $k_{\text {cat }}$. To obtain $k_{\text {cat }}$ and the apparent dissociation constant $K_{\mathrm{D}}$ of D5 binding to exD123, the $k_{\text {obs }}$ values were plotted as a function of D5 concentration (Fig. 4a) and fitted with Eq. 5 (see "Materials and methods") reflecting 1:1 binding behavior $[38,49]$. In the linear range of the reaction (Fig. 3b), exD123 is saturated with D5, i.e., single-turnover conditions are present and product release is not an issue. It is known that no rate-limiting conformational change occurs in the enzyme-substrate complex [24, 25], and $k_{\text {cat }}$ therefore reflects neither binding nor product release but is considered equal to the rate of the chemical step $k_{\text {chem }}$. The values we obtained- $k_{\text {cat }}=0.045 \pm 0.002 \mathrm{~min}^{-1}$ and $K_{\mathrm{D}}=169 \pm 30 \mathrm{nM}\left(100 \mathrm{mM} \mathrm{Mg}^{2+}, \mathrm{pH} 7.5\right)$-are in good agreement with previously reported results $\left(k_{\text {cat }}=0.041 \pm 0.001 \mathrm{~min}^{-1}, K_{\mathrm{D}}=270 \pm 25 \mathrm{nM}[38]\right)$.

Metal ions other than $\mathrm{Mg}^{2+}$ inhibit the trans-cleavage reaction

Metal ions other than $\mathrm{Mg}^{2+}$ are known to either inhibit or accelerate the reactions catalyzed by different ribozymes. Here, we chose to investigate the effect of a variety of metal ions that are commonly used in biochemistry and structural biology, i.e., $\mathrm{Mn}^{2+}, \mathrm{Ni}^{2+}, \mathrm{Zn}^{2+}, \mathrm{Cd}^{2+}, \mathrm{Pb}^{2+}$, and $\left[\mathrm{Co}\left(\mathrm{NH}_{3}\right)_{6}\right]^{3+}$, on the first step of splicing of Sc.ai5 $\gamma$ (Fig. 5). In the presence of $90 \mathrm{mM} \mathrm{Mg}^{2+}$ and $10 \mathrm{mM}$ concentration of each divalent metal ion (at a background of $0.5 \mathrm{M} \mathrm{KCl}$ ), the same trans-splicing reaction as described in the previous section was carried out and compared with the $\mathrm{Mg}^{2+}$-only reaction. Hence, all $\mathrm{M}^{2+}$ conditions had the same ionic strength $(I=0.8)$, except for the case of $\left[\mathrm{Co}\left(\mathrm{NH}_{3}\right)_{6}\right]^{3+}$, where $I=0.83$ and thus is slightly higher. All reactions were repeated at least three times and aliquots of the reaction mixture were quenched with formamide buffer at either 0,30 , and 90 min or 0,20 , 40 , and 90 or $105 \mathrm{~min}$. PAGE analysis revealed the familiar band pattern (Fig. 2) with decreasing intensities of the substrate exD123 and concomitantly increasing intensities of four product bands (Fig. 5).

As can be seen in Fig. $6, \mathrm{Mn}^{2+}$ has the least influence on the trans-splicing reaction: After $40 \mathrm{~min}, 82 \%$ of the substrate exD123 has been cleaved, compared with $88 \%$ in the presence of $\mathrm{Mg}^{2+}$ only. $\mathrm{Ca}^{2+}$ and $\mathrm{Cd}^{2+}$ both exhibit a comparable effect, with about $70 \%$ of substrate being cleaved. trans-Splicing in the presence of $10 \mathrm{mM}$ $\left[\mathrm{Co}\left(\mathrm{NH}_{3}\right)_{6}\right]^{3+}$ also works quite well, as still $64 \%$ cleavage occurs within $40 \mathrm{~min}$. In all of these cases, no enhanced unspecific cleavage of the RNA could be detected (Fig. 5). This is different for $\mathrm{Ni}^{2+}, \mathrm{Zn}^{2+}$, and $\mathrm{Pb}^{2+}$, which all show a strong inhibitory effect. For example, in the case of $\mathrm{Ni}^{2+}$, an $80 \%$ decrease in the intensity of the substrate band over the course of the reaction is observed, but no simultaneous increase in the product D123 was detected at any time

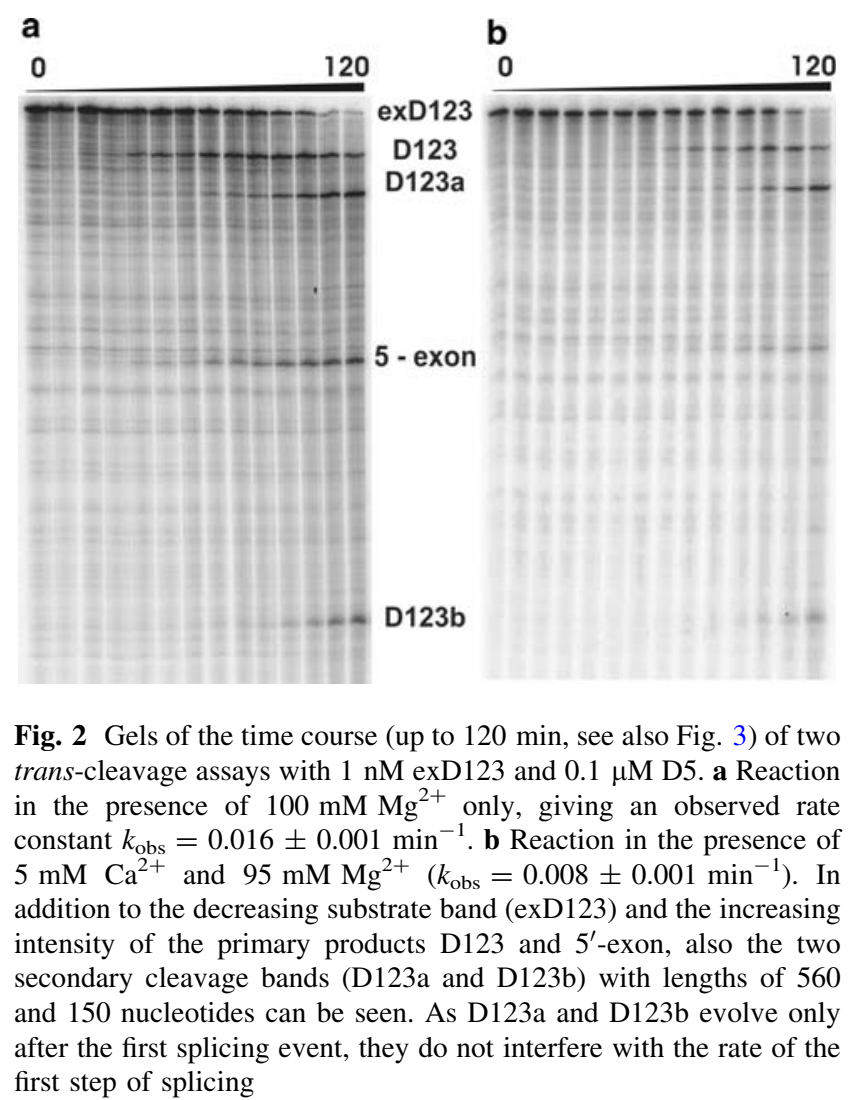



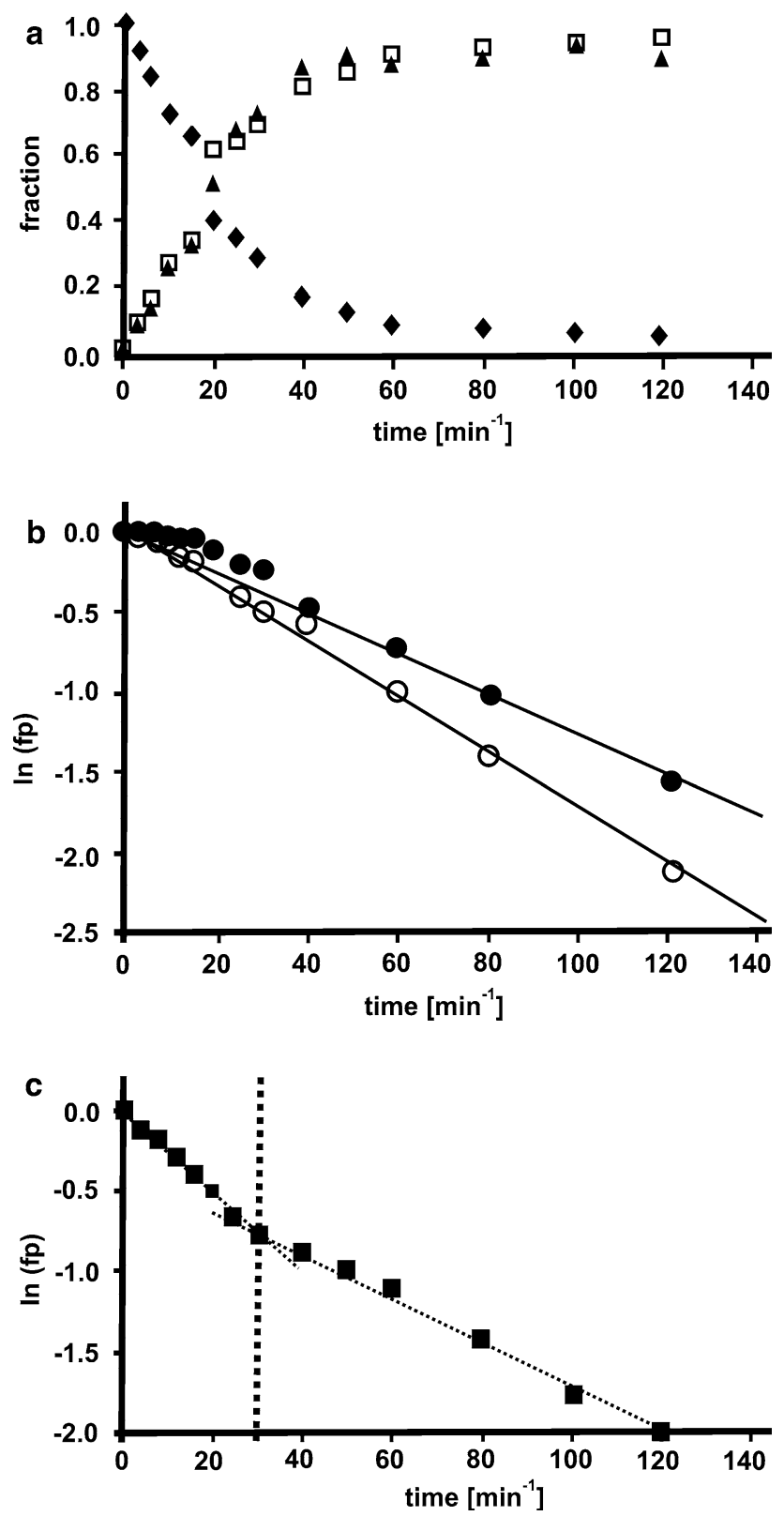

Fig. 3 Calculation of the observed rate constants $k_{\text {obs }}$ for the cleavage of $1 \mathrm{nM}$ exD123 by $1 \mu \mathrm{M}$ D5 in the presence of $\mathrm{Mg}^{2+}$ and $\mathrm{Ca}^{2+}$. a Time course for the cleavage of exD123 (diamonds) into D123 (squares) and $5^{\prime}$-exon (triangles) in the presence of $99 \mathrm{mM}$ $\mathrm{MgCl}_{2}$ and $1 \mathrm{mM} \mathrm{CaCl}_{2}$. The plots intersect at $50 \%$ of the reaction at $\tau_{1 / 2}=20$ min. b $\ln$ (fp) (with fp being the fraction of precursor) versus time for the splicing reaction in the presence of $100 \mathrm{mM}$ $\mathrm{MgCl}_{2}$ (open circles) as well as $99 \mathrm{mM} \mathrm{MgCl}$ and $1 \mathrm{mM} \mathrm{CaCl}$ (filled circles). $\mathrm{Ca}^{2+}$ clearly lowers the observed reaction rate $k_{\mathrm{obs}}$. $k_{\text {obs }}$ was calculated from the linear regression according to Eq. 1. c Active replacement of $\mathrm{Mg}^{2+}$ by $\mathrm{Ca}^{2+}$. The splicing reaction is initiated with $95 \mathrm{mM} \mathrm{Mg}^{2+}$ only. Addition of $5 \mathrm{mM} \mathrm{Ca}^{2+}$ after 30 min results in an immediate loss of the observed rate as is evident from the kink in the data profile. $k_{\mathrm{obs}}$ values before and after the addition of $\mathrm{Ca}^{2+}$ are comparable to the ones observed when the full time course was carried out in the presence of $95 \mathrm{mM} \mathrm{Mg}^{2+} / 5 \mathrm{mM}$ $\mathrm{Ca}^{2+}$ or $100 \mathrm{mM} \mathrm{Mg}^{2+}$ only, respectively (Table 2)
(Fig. 5). Hence, the decrease in substrate is solely due to unspecific degradation. A similar observation is made with $\mathrm{Zn}^{2+}$, whose presence leads to the complete degradation of the substrate exD123 within the first $30 \mathrm{~min}$. Again, no specific cleavage, i.e., splicing, was detected at any time in the course of the reaction. The addition of $10 \mathrm{mM} \mathrm{Pb}^{2+}$ also does not result in any specific splicing, but again leads to complete unspecific degradation of the substrate. In addition, a white precipitate could be observed after $10 \mathrm{~min}$ of incubation consisting most likely of lead-hydroxo species. Both $\mathrm{Zn}^{2+}$ and $\mathrm{Pb}^{2+}$ are well known to promote phosphate-diester hydrolysis. These two examples illustrate that the ability of a metal ion to activate a nucleophile and accelerate cleavage is not the sole requirement in group II intron splicing.

$\mathrm{Ca}^{2+}$ actively inhibits the trans-splicing reaction

In subsequent experiments we concentrated on the effect of $\mathrm{Ca}^{2+}$ on the splicing reaction, as this divalent metal ion occurs also freely in the cell, though tightly regulated. Experiments analogous to those described in the previous section were carried out in presence of various amounts of $\mathrm{CaCl}_{2}$. Using $1 \mathrm{nM}$ exD123 and $3 \mu \mathrm{M}$ D5, we detected no product formation in either $100 \mathrm{mM} \mathrm{CaCl}{ }_{2}$ alone or $1: 1$ mixtures of $\mathrm{MgCl}_{2}$ and $\mathrm{CaCl}_{2}$ at either 50 or $100 \mathrm{mM}$ concentration each (data not shown). Ribozyme constructs of $S c$.ai5 $\gamma$ are known to be correctly folded and active in

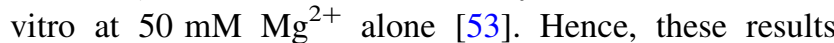
already illustrate that $\mathrm{Ca}^{2+}$ cannot substitute $\mathrm{Mg}^{2+}$ in order to reach the active fold. Furthermore, $\mathrm{Ca}^{2+}$ obviously interferes with $\mathrm{Mg}^{2+}$ binding either during folding or in the active complex, thereby completely inhibiting the first step of splicing under these conditions.

To gain further information on the competition between $\mathrm{Mg}^{2+}$ and $\mathrm{Ca}^{2+}$ binding and the effect on splicing of the group II intron $S c$.ai5 $\gamma$, we performed a series of trans-cleavage assays at lower $\mathrm{Ca}^{2+}$ concentrations, i.e., 1-5 $\mathrm{mM} \mathrm{CaCl}_{2}$. The ionic strength of the reaction mixtures was kept constant by complementing $100 \mathrm{mM} \mathrm{M}^{2+}$ with $\mathrm{MgCl}_{2}$. In this way, the kinetic profiles of the reactions with different $\mathrm{Ca}^{2+}$ concentrations can be directly compared with each other. Under all $\mathrm{Ca}^{2+}$ concentrations applied (1-5 mM), the splicing reaction still obey pseudofirst-order kinetics up to at least $60 \mathrm{~min}$. At later times, deviation from linearity is observed because random hydrolysis becomes significant as has also previously been described with $\mathrm{Mg}^{2+}$ only [38]. Using the data points in the linear range of each experiment, we calculated the observed rates $k_{\mathrm{obs}}$ and $\tau_{1 / 2}$, the half-time of the reaction (Eqs. 1, 2, Fig. 3b). Irrespective of the $\mathrm{Mg}^{2+}$-to- $\mathrm{Ca}^{2+}$ ratio applied, the reaction becomes faster with increasing D5 
Table 1 Observed first-order rate constants $k_{\text {obs }}$, reaction half-times $\tau_{1 / 2}$, and maximal turnover rates $k_{\text {cat }}$ for the trans-cleavage experiments of $1 \mathrm{nM}$ exD123 with $0.1 \mu \mathrm{M}$ D5 for the $\mathrm{Mg}^{2+}$-to-Ca ${ }^{2+}$ ratios

\begin{tabular}{lllll}
\hline $\mathrm{Mg}^{2+}$-to-Ca & & & $k_{\text {cat }}\left(\mathrm{min}^{-1}\right)$ & $K_{\mathrm{D}}$ \\
\hline $100: 0$ & $k_{\text {obs }}\left(\mathrm{min}^{-1}\right)$ & $43.3 \pm 2.7$ & $0.045 \pm 0.002$ & $168.7 \pm 29.7$ \\
$99: 1$ & $0.016 \pm 0.001$ & $57.8 \pm 4.8$ & $0.044 \pm 0.002$ & $348.2 \pm 65.0$ \\
$98: 2$ & $0.012 \pm 0.001$ & $53.3 \pm 4.1$ & $0.041 \pm 0.005$ & $291.1 \pm 162.0$ \\
$96: 4$ & $0.013 \pm 0.001$ & $63.0 \pm 11.4$ & $0.031 \pm 0.002$ & $122.2 \pm 44.4$ \\
$95: 5$ & $0.011 \pm 0.002$ & $86.6 \pm 10.8$ & $0.023 \pm 0.001$ & $154.2 \pm 43.6$ \\
\hline
\end{tabular}

indicated. The dissociation constants $K_{\mathrm{D}}$ for D5 binding to exD123 for each $\mathrm{Mg}^{2+}$-to- $\mathrm{Ca}^{2+}$ ratio are given in the last column
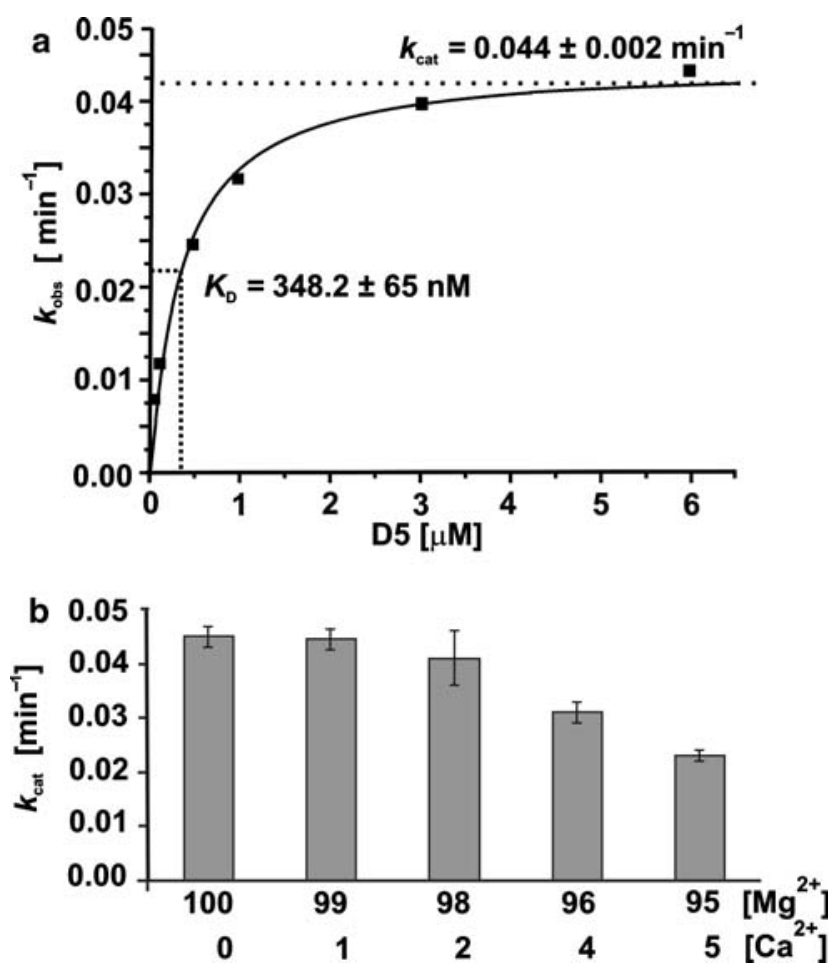

Fig. 4 Determination of $k_{\mathrm{cat}}$ and $K_{\mathrm{D}}$. a $k_{\mathrm{obs}}$ values versus D5 concentration fitted to a 1:1 bimolecular association curve (Eq. 5). For the experiment shown $\left(99 \mathrm{mM} \mathrm{MgCl} 2\right.$ and $1 \mathrm{mM} \mathrm{CaCl}_{2}$ ), the maximal turnover rate at D5 saturation $k_{\text {cat }}=0.044 \pm 0.002 \mathrm{~min}^{-1}$ and a dissociation constant of D5 towards exD123 $K_{\mathrm{D}}=$ $348.2 \pm 65 \mathrm{nM}$ were obtained. b Decrease of $k_{\text {cat }}$ with increasing concentrations of $\mathrm{Ca}^{2+}$ in the reaction mixture. A concentration of only $5 \mathrm{mM} \mathrm{Ca}^{2+}$ in excess of $95 \mathrm{mM} \mathrm{Mg}^{2+}$ slows the rate of the trans-cleavage reaction down to about one half

concentrations as is expected for a Michaelis-Menten behavior. The experimental data obtained for the different $\mathrm{Mg}^{2+}$-to- $\mathrm{Ca}^{2+}$ ratios were evaluated analogously to those for the $\mathrm{Mg}^{2+}$-only case described in the previous section, yielding $k_{\text {cat }}$ and $K_{\mathrm{D}}$ values (Fig. 4). The dissociation constants $K_{\mathrm{D}}$ for D5 binding to exD123 vary between 120 and $560 \mathrm{nM}$, which is in a range of values published before for the $\mathrm{Mg}^{2+}$-only case [38, 52]. No obvious dependence of $K_{\mathrm{D}}$ versus $\mathrm{Ca}^{2+}$ concentration (Table 1) was observed, 
Fig. 5 trans-Cleavage assays in the presence of $90 \% \mathrm{Mg}^{2+}$ and $10 \mathrm{mM}$ of another metal ion. Shown are the cleavage patterns at reaction times of 0,30 , and 90 min each. The control lane (c) contains only exD123 and lane 2 exD123, $500 \mathrm{mM} \mathrm{KCl}$, and $40 \mathrm{mM}$ MOPS (pH 7.2), but no divalent metal ions

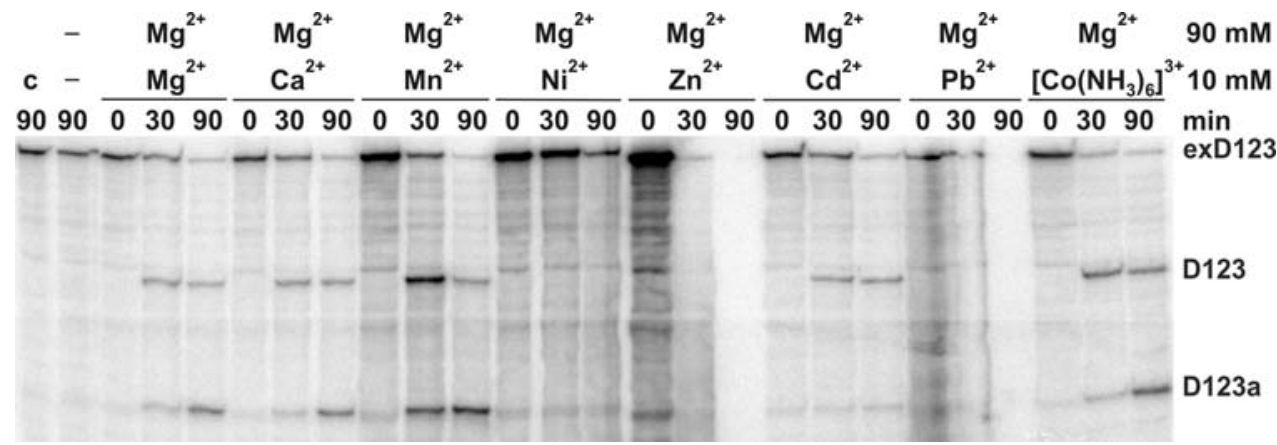

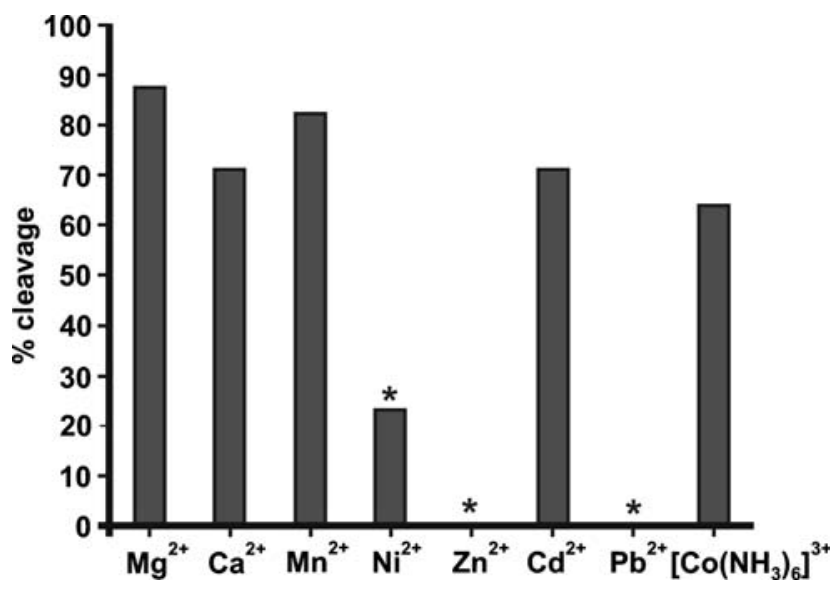

Fig. 6 Percentage of exD123 spliced after $40 \mathrm{~min}$ of the transcleavage reaction in the presence of $90 \mathrm{mM} \mathrm{Mg}^{2+}$ and $10 \mathrm{mM} \mathrm{Ca}^{2+}$, $\mathrm{Mn}^{2+}, \mathrm{Ni}^{2+}, \mathrm{Zn}^{2+}, \mathrm{Cd}^{2+}, \mathrm{Pb}^{2+}$, or $\left[\mathrm{Co}\left(\mathrm{NH}_{3}\right)_{6}\right]^{3+}$. In the case of $\mathrm{Ni}^{2+}$, $\mathrm{Zn}^{2+}$, and $\mathrm{Pb}^{2+}$, exD123 degrades without the appearance of product bands at any time (marked with an asterisk), i.e., these three metal ions completely inhibit splicing

extent that only a time span up to 40 min could be used for the kinetic analysis. For this reason we did not routinely preincubate the individual components before the reaction.

The extended time that exD123 and D5 need to assemble to the active species in the presence of small amounts of $\mathrm{Ca}^{2+}$ strongly indicates that $\mathrm{Ca}^{2+}$ also interferes with the folding pathway. Considering that the $K_{\mathrm{D}}$ values for D5 binding to exD123 show no dependence on $\mathrm{Ca}^{2+}$ concentration, it seems likely that the interference of $\mathrm{Ca}^{2+}$ occurs earlier, i.e., during the collapse of D1.

$\mathrm{Ca}^{2+}$ competes actively with $\mathrm{Mg}^{2+}$ for its binding site

In the previous sections we have shown that $\mathrm{Ca}^{2+}$ interferes with both catalysis and folding, when added simultaneously with $\mathrm{Mg}^{2+}$ to the reaction mixture containing exD123 and D5. Obviously, in such an experimental setup, both alkaline earth metal ions have a priori the same chance to bind to any metal ion binding site within the active three-dimensional exD123/D5 complex. $\mathrm{Mg}^{2+}$ is always present in excess, which means that $\mathrm{Ca}^{2+}$ must bind more strongly to at least one certain site. It is an open question whether $\mathrm{Ca}^{2+}$ binds to a site(s) unoccupied by $\mathrm{Mg}^{2+}$ or replaces $\mathrm{Mg}^{2+}$, or both. However, in order to both slow down folding and inhibit catalysis, it is most likely that several $\mathrm{Ca}^{2+}$ ions are involved in the process.

To examine whether the inhibiting $\mathrm{Ca}^{2+}$ ion(s) needs to be incorporated during the folding process, or if $\mathrm{Ca}^{2+}$ can actively displace $\mathrm{Mg}^{2+}$ from the crucial binding site(s) once the ribozyme has folded, we performed an "on-pathway" inhibition experiment. The splicing reaction was initiated in the presence of $95 \mathrm{mM} \mathrm{Mg}^{2+}$ only. At a specific time (12 or $30 \mathrm{~min}$ after the start), $5 \mathrm{mM} \mathrm{CaCl}_{2}$ was added to the reaction mixture. Plotting product formation versus time reveals a sharp kink at the time when $5 \mathrm{mM} \mathrm{Ca}^{2+}$ was added to the reaction mixture (Fig. 3c). Separate analysis of the data before and after $\mathrm{Ca}^{2+}$ addition yielded two different $k_{\text {obs }}$ values. At a concentration of $0.1 \mu \mathrm{M}$ D5 and addition of $\mathrm{Ca}^{2+} 30$ min after the start of the reaction, $k_{\text {obs } / 30 \mathrm{a}}=$ $0.19 \mathrm{~min}^{-1}$ (before addition of $\mathrm{Ca}^{2+}$ ) and $k_{\text {obs/ }}$ $30 \mathrm{~b}=0.007 \mathrm{~min}^{-1}$ (after addition of $\mathrm{Ca}^{2+}$ ) were obtained (Table 2). Both values agree surprisingly well within their error limits with the respective $k_{\text {obs }}$ values determined in the presence of $\mathrm{Mg}^{2+}$ only and a 95:5 mixture of the two divalent metal ions (0.16 and $0.008 \mathrm{~min}^{-1}$, respectively). Similar values were obtained from experiments where $\mathrm{Ca}^{2+}$ was added after $12 \mathrm{~min}$ (Table 2). This result clearly shows that $\mathrm{Ca}^{2+}$ is able to actively displace $\mathrm{Mg}^{2+}$ from its binding site even within the core of the folded ribozyme.

\section{Discussion}

$\mathrm{Mg}^{2+}$ is an essential cofactor for the large group II intron ribozymes, being necessary for folding into the active tertiary structure as well as for catalysis [21, 53, 56-59]. Although the effect of metal ions on catalytic RNA has been studied extensively with ribozymes other than group II introns [5, 9, 29, 35, 60-66], it is still not known in detail how divalent metals influence the catalytic efficiency of these molecular machines. 
Table 2 Observed rates $k_{\mathrm{obs}}$ for the trans-cleavage reaction with $1 \mathrm{nM}$ exD123 and a series of D5 concentrations carried out in $95 \mathrm{mM} \mathrm{Mg}^{2+}$ with $5 \mathrm{mM} \mathrm{Ca}^{2+}$ added after 12 and $30 \mathrm{~min}$, respectively. The plot of $\ln (\mathrm{fp})$ versus time shows a sharp kink at the time of $\mathrm{Ca}^{2+}$ addition (Fig. $\left.3 \mathrm{c}\right)$. Before $\mathrm{Ca}^{2+}$ addition $\left(k_{\mathrm{obs} / 12 \mathrm{a}}\right.$ and $\left.k_{\mathrm{obs} / 30 \mathrm{a}}\right)$, the observed rate constants $k_{\text {obs }}$ are comparable to the ones measured in $100 \mathrm{mM} \mathrm{Mg}^{2+} k_{\text {obs } / 100}$ (columns 2-4). After $\mathrm{Ca}^{2+}$ addition $\left(k_{\mathrm{obs} / 12 \mathrm{~b}}\right.$ and $k_{\mathrm{obs} / 30 \mathrm{~b}}$ ), the reaction slows down to rates close to the ones measured for the trans-cleavage assays in $95 \mathrm{mM} \mathrm{Mg}^{2+}$ and $5 \mathrm{mM}$ $\mathrm{Ca}^{2+}$, i.e., $k_{\text {obs/95 }}$ (columns 5-7). D5 concentrations are given in micromoles per liter and the rates in per minute, with errors corresponding to at least one standard deviation

\begin{tabular}{lllllll}
\hline D5 & $k_{\text {obs } / 100}$ & $k_{\text {obs } / 12 \mathrm{a}}$ & $k_{\text {obs/30a }}$ & $k_{\text {obs } / 95}$ & $k_{\text {obs } / 12 \mathrm{~b}}$ & $k_{\text {obs/30b }}$ \\
\hline 0.05 & $0.012 \pm 0.001$ & $-{ }^{\mathrm{a}}$ & $0.012 \pm 0.001$ & $0.007 \pm 0.001$ & $0.008 \pm 0.001$ & $0.006 \pm 0.001$ \\
0.10 & $0.016 \pm 0.001$ & $0.013 \pm 0.001$ & $0.019 \pm 0.001$ & $0.008 \pm 0.001$ & $0.008 \pm 0.001$ & $0.007 \pm 0.001$ \\
1.00 & $0.037 \pm 0.005$ & $0.041 \pm 0.002$ & $0.041 \pm 0.001$ & $0.022 \pm 0.001$ & $0.033 \pm 0.001$ & $-{ }^{\mathrm{a}}$
\end{tabular}

${ }^{a}$ These rates could not be determined with good enough accuracy because of either too slow a reaction $\left(k_{\mathrm{obs} / 12 \mathrm{a}}\right)$ or not enough time in the linear phase of the splicing reaction $\left(k_{\mathrm{obs} / 30 \mathrm{~b}}\right)$

Here we studied the effect of various metal ions on group II intron splicing, choosing $S c$.ai5 $\gamma$ as one of the best characterized ribozymes of this class. We thereby focused on the effect of $\mathrm{Ca}^{2+}$ because $S c$.ai5 $\gamma$ resides in the mitochondria, one of the cell's main $\mathrm{Ca}^{2+}$ storage sites. $\mathrm{Ca}^{2+}$ is a physiologically very important metal ion, e.g., playing roles in homeostasis of the cell in general, in $\mathrm{Ca}^{2+}$ signaling [67, 68], enzyme activation [69], and energy production [70]. Thus, concentrations of $\mathrm{Ca}^{2+}$ in living cells are strictly regulated. Mitochondria sequester and release $\mathrm{Ca}^{2+}$ with high efficiency [67, 68, 71-74]. Apart from its role in $\mathrm{Ca}^{2+}$ homeostasis, mitochondrial $\mathrm{Ca}^{2+}$ also seems to be important in cell apoptosis: overexpression of antiapoptotic Bcl-2, which is preferentially located in mitochondria, leads to a greatly increased $\mathrm{Ca}^{2+}$ uptake capacity of such cells $[42,67,75]$. Furthermore, release of cytochrome $c$ from the mitochondrial intermembrane compartment is thought to activate caspases and eventually lead to apoptosis of the cell [76]. Although the role of cytochrome $c$ in apoptosis is thought to be independent of its respiratory function, it is striking that $S c$.ai $5 \gamma$, whose self-splicing activity can be impaired by $\mathrm{Ca}^{2+}$ in vitro, resides in the yeast cytochrome $c$ oxidase gene I [77], suggesting a potential role in apoptosis in vivo.

Our mixed metal ion studies reveal an inhibitory effect of $\mathrm{Ca}^{2+}$ on self-splicing already at a concentration of

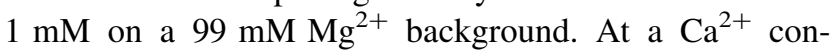
centration of $5 \mathrm{mM}$, the turnover rate $k_{\text {cat }}$ is reduced by one half from $0.045 \pm 0.02 \mathrm{~min}^{-1}$ at $100 \mathrm{mM} \mathrm{Mg}^{2+}$ to $0.023 \pm 0.01 \mathrm{~min}^{-1}$ (Table 1). A reduction in cleavage rate solely due to the lower concentration of $\mathrm{Mg}^{2+}$ can be excluded for the following reason: upon addition of $\mathrm{Mg}^{2+}$, $S c$.ai5 $\gamma$ folds directly to the active state with a midpoint of 40-50 $\mathrm{mM} \mathrm{Mg}^{2+}$ [25]. Hence, above $90 \mathrm{mM} \mathrm{Mg}^{2+} \mathrm{a}$ change in concentration should only have very small effects. Indeed, the rates measured at 100 and $95 \mathrm{mM} \mathrm{Mg}{ }^{2+}$ correspond to each other within error limits of three standard deviations (Table 2).
Intriguingly, even if $\mathrm{Ca}^{2+}$ is added to the reaction mixture at a later time, this metal ion clearly inhibits product formation as is evident by the sharp kink in the semilogarithmic plot of the decrease of the precursor fraction versus time (Fig. 3). All these results are a clear indication that $\mathrm{Ca}^{2+}$ is able to actively replace $\mathrm{Mg}^{2+}$ from at least one of its binding sites and consequently inhibit splicing. Evidently such an exchange of the two alkaline earth ions can only take place if the affinity of $\mathrm{Ca}^{2+}$ to the binding site is higher than that of the naturally applied $\mathrm{Mg}^{2+}$. The amount of increased $\mathrm{Ca}^{2+}$ affinity at this site can be estimated: a $50 \%$ reduction in the catalytic rate $k_{\text {cat }}$ is achieved in the presence of a 20-fold excess of $\mathrm{Mg}^{2+}$ over $\mathrm{Ca}^{2+}$. Assuming that the binding of $\mathrm{Ca}^{2+}$ at a specific site leads to a total (i.e., 99\%) loss in activity, its affinity must be about 2,000 times higher than that for $\mathrm{Mg}^{2+}$ at the site of displacement.

How do these findings compare with the ligand binding properties and known affinity constants of these two metal ions to nucleotides? Both alkaline earth metal ions prefer oxygen donor ligands over the softer nitrogen, but being below $\mathrm{Mg}^{2+}$ in the periodic table, $\mathrm{Ca}^{2+}$ has an ionic radius which is about $40 \%$ larger (100 pm, compared with 72 pm; Table 3) [78, 79]. Consequently, the cation-to-ligand distance is also longer (237 vs. 204 pm) [80]. Owing to the difference in size also the coordination numbers differ slightly: whereas $\mathrm{Mg}^{2+}$ is generally octahedral, $\mathrm{Ca}^{2+}$ often binds eight donor atoms [79]. On the basis of these different coordinating properties, it is expected that $\mathrm{Ca}^{2+}$ forms weaker complexes. Indeed, the measured stability constants for the M(AMP) complexes (AMP ${ }^{2-}$ is adenosine $5^{\prime}$-monophosphate) $\log K_{\mathrm{Mg}(\mathrm{AMP})}^{\mathrm{Mg}}=1.60 \pm 0.02$ and $\log K_{\mathrm{Ca}(\mathrm{AMP})}^{\mathrm{Ca}}=$ $1.46 \pm 0.02[81]$ or the $\mathrm{M}(\mathrm{ATP})^{2-}$ complexes $\left(\mathrm{ATP}^{4-}\right.$ is adenosine 5'-triphosphate) $\log K_{\mathrm{Mg}(\mathrm{ATP})}^{\mathrm{Mg}}=4.29 \pm 0.03$ and $\log K_{\mathrm{Ca}(\mathrm{ATP})}^{\mathrm{Ca}}=3.91 \pm 0.03$ [82] illustrate the different coordinating strengths. Similar differences are found for related nucleotides and derivatives thereof $[39,83,84]$. 
Table 3 Comparison of some physicochemical properties of $\mathrm{Mg}^{2+}$, $\mathrm{Ca}^{2+}, \mathrm{Mn}^{2+}, \mathrm{Ni}^{2+}, \mathrm{Zn}^{2+}, \mathrm{Cd}^{2+}$, and $\mathrm{Pb}^{2+}$ in aqueous solution. Given are the ionic radii [78] and the preferred coordination number $(\mathrm{CN})$ of the $\mathrm{M}^{2+}$ ions, the enthalpy of hydration $\left(\Delta \mathrm{H}_{\text {hydr }}\right)[80]$, the distance between the metal ion and a coordinated water molecule [80, 94], the acidity constant $\mathrm{p} K_{\mathrm{M}\left(\mathrm{H}_{2} \mathrm{O}\right)_{6}}^{\mathrm{H}}$ of a water molecule in the hexa-aqua complex [95], as well as the ligand-exchange rate from the first coordination sphere of the metal ion $\left(k_{\text {exch }}\right)$ [96-99]

\begin{tabular}{|c|c|c|c|c|c|c|c|}
\hline & $\mathrm{Mg}^{2+}$ & $\mathrm{Ca}^{2+}$ & $\mathrm{Mn}^{2+}$ & $\mathrm{Ni}^{2+}$ & $\mathrm{Zn}^{2+}$ & $\mathrm{Cd}^{2+}$ & $\mathrm{Pb}^{2+}$ \\
\hline Ionic radius (pm) & 72 & $100(112)^{\mathrm{a}}$ & $83^{\mathrm{b}}$ & 69 & $74^{\mathrm{c}}$ & 95 & 119 \\
\hline $\mathrm{CN}$ & 6 & $6(8)^{\mathrm{a}}$ & 6 & 6 & 4 & 6 & $-^{\mathrm{d}}$ \\
\hline Preferred ligands & $\mathrm{O}$ & $\mathrm{O}$ & $\mathrm{O} / \mathrm{N}$ & $\mathrm{N} / \mathrm{O}$ & $\mathrm{N} / \mathrm{O}$ & $\mathrm{N} / \mathrm{O}$ & $\mathrm{O}$ \\
\hline$\Delta \mathrm{H}_{\text {hydr }}\left(\mathrm{kJ} \mathrm{mol}^{-1}\right)$ & 1858 & $1570(1,657)^{\mathrm{a}}$ & 1762 & 1950 & 1871 & 1640 & 1431 \\
\hline $\mathrm{M} \cdots \mathrm{OH}_{2}(\AA)$ & 2.04 & $2.37(2.48)^{\mathrm{a}}$ & 2.18 & 2.12 & 2.15 & 2.35 & 2.60 \\
\hline $\mathrm{p} K_{\mathrm{M}\left(\mathrm{H}_{2} \mathrm{O}\right)_{6}}^{\mathrm{H}}\left(25^{\circ} \mathrm{C}\right)$ & 11.44 & 12.85 & 10.59 & 9.86 & $8.96^{\mathrm{e}}$ & 10.2 & 7.8 \\
\hline$k_{\mathrm{exch}}\left(\mathrm{s}^{-1}\right)$ & $6.7 \times 10^{5}$ & $\approx 10^{9}$ & $2.1 \times 10^{7}$ & $3.2 \times 10^{4}$ & $4.1 \times 10^{8}$ & $6.8 \times 10^{8}$ & $1.0 \times 10^{10}$ \\
\hline
\end{tabular}

a The numbers in parentheses refer to $\mathrm{CN}=8$

${ }^{\mathrm{b}}$ High-spin electron configuration

c For $\mathrm{CN}=6$

${ }^{\mathrm{d}} \mathrm{Pb}^{2+}$ has no really preferred coordination number. It can be $4,6,7,8$, or 9 . The value given refers to $\mathrm{CN}=6$ [79]

e With other liganding sites present in the coordination sphere of $\mathrm{Zn}^{2+}$, the $\mathrm{p} K_{\mathrm{a}}$ value for hydrolysis is shifted towards the neutral $\mathrm{pH}$ range [100]

The ligand-exchange rate of $\mathrm{Ca}^{2+}$ is about 1,000-fold faster than that of $\mathrm{Mg}^{2+}\left(10^{9}\right.$ vs. $10^{6} \mathrm{~s}^{-1}$; Table 3$)$, suggesting that $\mathrm{Ca}^{2+}$ binds faster to the RNA during the folding process and later on is removed by $\mathrm{Mg}^{2+}$ owing to the difference in binding affinity. If such a mechanism of inhibition takes place, one should observe only an initial decline in rate. Indeed, the initial folding process upon addition of $\mathrm{Mg}^{2+}$ ions is inhibited by $\mathrm{Ca}^{2+}$, as, e.g., in the presence of $1 \% \mathrm{Ca}^{2+}$ product formation can only be detected after $10 \mathrm{~min}$ (Fig. 3b). However, as soon as all $\mathrm{Ca}^{2+}$ ions have been replaced by $\mathrm{Mg}^{2+}$, the full rate of splicing should be reconstituted. In contrast, we find that $\mathrm{Ca}^{2+}$ inhibits the splicing reaction itself even in a large excess of $\mathrm{Mg}^{2+}$. This suggests the presence of at least one crucial binding pocket that is "optimized" for $\mathrm{Ca}^{2+}$, possibly by being too large for $\mathrm{Mg}^{2+}$ and by offering more donor sites for $\mathrm{Ca}^{2+}$. The presence of a specific binding site for $\mathrm{Ca}^{2+}$ is corroborated by the observation that addition of $\mathrm{Ca}^{2+}$ to the ongoing splicing reaction of the folded ribozyme slows down the reaction immediately. A specificity for $\mathrm{Ca}^{2+}$ over $\mathrm{Mg}^{2+}$ is already known from low molecular weight complexes as well as certain proteins: e.g., the ligand Bistris forms an approximately 80 times more stable complex with $\mathrm{Ca}^{2+}$ than with $\mathrm{Mg}^{2+}\left(\log K_{\mathrm{Mg}(\text { Bistris })}^{\mathrm{Mg}}=\right.$ $0.34 \pm 0.05$ and $\left.\log K_{\mathrm{Ca}(\text { Bistris })}^{\mathrm{Ca}}=2.25 \pm 0.02\right)$ [85] and certain sites in the protein calbindin $\mathrm{D}_{9 \mathrm{k}}$ do not bind $\mathrm{Mg}^{2+}$ even in absence of $\mathrm{Ca}^{2+}[86]$.

At this point one may speculate what the local effect of $\mathrm{Ca}^{2+}$ in the group II intron $S c$.ai5 $\gamma$ might be: the replacement of $\mathrm{Mg}^{2+}$ by $\mathrm{Ca}^{2+}$ at a specific site may lead to a local geometrical change and thus interrupt a crucial tertiary interaction, or even alter the catalytic core itself.
Considering the fast and large changes in $\mathrm{Ca}^{2+}$ concentration within mitochondria, a possible effect on splicing of $S c$.ai5 $\gamma$ in vivo is an interesting possibility.

Similarly to $\mathrm{Ca}^{2+}$ also other divalent metal ions lead to an inhibition of the splicing reaction (Fig. 6). $\mathrm{Mn}^{2+}$ seems to be the best substitute for $\mathrm{Mg}^{2+}$ in group II introns, as the trans-cleavage reaction is hardly inhibited. $\mathrm{Mn}^{2+}$ is slightly larger than $\mathrm{Mg}^{2+}$ (83 vs. $72 \mathrm{pm}$; Table 3) but has the same preference for an octahedral coordination sphere [78, 79]. According to the Irving-Williams series [87] its complexes are in general slightly more stable than those of $\mathrm{Mg}^{2+}$. The hammerhead ribozyme [10], the Tetrahymena ribozyme [88], and ribonuclease $\mathrm{P}$ [89] have been shown to be active or sometimes even accelerated in the presence of $\mathrm{Mn}^{2+}$. It is therefore no surprise that a certain portion of the $\mathrm{Mg}^{2+}$ needed for the splicing reaction of $S c$.ai5 $\gamma$ can be replaced by $\mathrm{Mn}^{2+}$.

It is interesting to note that exD123 is spliced in the presence of $\left[\mathrm{Co}\left(\mathrm{NH}_{3}\right)_{6}\right]^{3+}$, albeit more slowly than with $\mathrm{Mg}^{2+}$ alone. Because of its inert $\mathrm{NH}_{3}$ ligands, $\left[\mathrm{Co}\left(\mathrm{NH}_{3}\right)_{6}\right]^{3+}$ may replace $\mathrm{Mg}^{2+}$ without much distortion of the local RNA structure only at binding sites which require an exclusively outer-sphere coordination mode of $\mathrm{Mg}^{2+}$. At sufficiently high concentrations of $\mathrm{Mg}^{2+},\left[\mathrm{Co}\left(\mathrm{NH}_{3}\right)_{6}\right]^{3+}$ will thus coordinate only to outer-sphere binding sites, whereas partly inner-sphere binding sites can still be occupied by $\left[\mathrm{Mg}\left(\mathrm{H}_{2} \mathrm{O}\right)_{m}\right]^{n+}$.

Interestingly, $\mathrm{Cd}^{2+}$, having an ionic radius comparable in size to that of $\mathrm{Ca}^{2+}$, slows down the splicing reaction to about the same extent. However, $\mathrm{Cd}^{2+}$ has a much higher affinity towards nitrogen ligands than $\mathrm{Ca}^{2+}$ and is expected to replace $\mathrm{Mg}^{2+}$ only very selectively, i.e., only if innersphere coordination to a $\mathrm{N} 7$ position of a purine nucleobase 
residue can take place [35]. These results therefore underline the notion that besides a reasonably high affinity of a given metal ion also its individual coordinating properties as well as the accessibility of certain binding sites play an important role in the specific metal ion binding within group II introns.

The remaining metal ions examined exhibit a different effect (Fig. 6): $\mathrm{Zn}^{2+}$ and $\mathrm{Pb}^{2+}$ lead to a fast nonspecific degradation of the substrate (Fig. 5). Indeed, both metal ions have a high affinity for phosphate residues and a significant tendency to form hydroxo complexes. Thus, they are ideal cations to activate water for nucleophilic attacks in the physiological $\mathrm{pH}$ range and $\mathrm{Zn}^{2+}$ is for such a purpose also found in nucleases [90, 91]. Hence, the observed nonspecific degradation effects are not too surprising. $\mathrm{Ni}^{2+}$ fits into the same picture, having a comparable phosphate affinity but in addition a more pronounced affinity towards nitrogen sites and a smaller tendency to form hydroxo complexes [92]. Indeed, also in the presence of $\mathrm{Ni}^{2+}$ a nonspecific cleavage is observed but with a lower effectiveness than $\mathrm{Zn}^{2+}$ and $\mathrm{Pb}^{2+}$ (Fig. 5).

In the cases of the P4-P6 domain of the Tetrahymena group I intron [93] and the hammerhead ribozyme [9], it has been shown that the effect of different metal ions on folding and catalysis, respectively, follows to a large extent the Irving-Williams series. In the case of $S c$.ai5 $\gamma$, no such trend following the Irving-Williams series [87] or the stability ruler of Martin [79] can be observed. It thus appears that in group II introns, or most likely in large RNAs in general, specific binding pockets exist, which bind metal ions other than $\mathrm{Mg}^{2+}$ much more tightly and more selectively. Whether such a selectivity and specificity has evolved on purpose, i.e., providing the organism with a means to fine-tune the reactivity of a given naturally occurring ribozyme, or if the resulting acceleration or inhibition happens by chance remains to be seen.

Acknowledgments We thank Maya Furler for the plasmid preparations and her as well as Olga Fedorova from Yale University for helpful discussions, and Michael Wächter for performing preliminary experiments. The plasmids pJD3'-673 and pJD15'-75 were a generous gift from Anna Marie Pyle from Yale University. Financial support from the Swiss National Science Foundation (SNF-Förderungsprofessur to R.K.O.S., PP002-114759/1) is also gratefully acknowledged.

\section{References}

1. Gesteland RF, Cech TR, Atkins JF (2006) The RNA world. Cold Spring Harbor Press, New York

2. Joyce GF (1993) Pure Appl Chem 65:1205-1212

3. Beaudry AA, Joyce GF (1992) Science 257:635-641

4. Kazakov S, Altman S (1992) Proc Natl Acad Sci USA 89:79397943

5. Sigel RKO, Pyle AM (2007) Chem Rev 107:97-113

6. O'Rear JL, Wang S, Feig AL, Beigelman L, Uhlenbeck OC, Herschlag D (2001) RNA 7:537-545
7. Murray JB, Seyhan AA, Walter NG, Burke JM, Scott WG (1998) Chem Biol 5:587-595

8. Curtis EA, Bartel DP (2001) RNA 7:546-552

9. Roychowdhury-Saha M, Burke DH (2006) RNA 12:1846-1852

10. Dahm SC, Uhlenbeck OC (1991) Biochemistry 30:9464-9469

11. Chowrira BM, Berzal-Herranz A, Burke JM (1993) Biochemistry 32:1088-1095

12. Li J, Lu Y (2000) J Am Chem Soc 122:10466-10467

13. Santoro SW, Joyce GF (1997) Proc Natl Acad Sci USA 94:4262-4266

14. Faulhammer D, Famulok M (1997) J Mol Biol 269:188-202

15. Faulhammer D, Famulok M (1996) Angew Chem Int Ed 35:2837-2841

16. Li J, Zheng WC, Kwon AH, Lu Y (2000) Nucleic Acids Res 28:481-488

17. Lehman N, Joyce GF (1993) Nature 361:182-185

18. Lehman N, Joyce GF (1993) Curr Biol 3:723-734

19. Burton AS, Lehman N (2006) Biochimie 88:819-825

20. Costa M, Fontaine JM, Goër SL, Michel F (1997) J Mol Biol 274:353-364

21. Pyle AM (2002) J Biol Inorg Chem 7:679-690

22. Sigel RKO (2005) Eur J Inorg Chem 12:2281-2292

23. Waldsich C, Pyle AM (2008) J Mol Biol 375:572-580

24. Waldsich C, Pyle AM (2007) Nat Struct Mol Biol 14:37-44

25. Fedorova O, Zingler N (2007) Biol Chem 388:665-678

26. Gordon PM, Piccirilli JA (2001) Nat Struct Biol 8:893-898

27. Toor N, Keating KS, Taylor SD, Pyle AM (2008) Science 320:77-82

28. Hertweck M, Müller MW (2001) Eur J Biochem 268:4610-4620

29. Sigel RKO, Pyle AM (2003) Met Ions Biol Syst 40:477-512

30. Sigel RKO, Vaidya A, Pyle AM (2000) Nat Struct Biol 7:11111116

31. Boudvillain M, de Lencastre A, Pyle AM (2000) Nature 406:315-318

32. Boudvillain M, Pyle AM (1998) EMBO J 17:7091-7104

33. Fedorova O, Pyle AM (2005) EMBO J 24:3906-3916

34. Gordon PM, Fong R, Piccirilli JA (2007) Chem Biol 14:607612

35. Freisinger E, Sigel RKO (2007) Coord Chem Rev 251:18341851

36. Furler M, Knobloch B, Sigel RKO (2008) Inorg Chim Acta. doi: 10.1016/j.ica.2008.1003.1095

37. Fedorova O, Su LJ, Pyle AM (2002) Methods 28:323-335

38. Pyle AM, Green JB (1994) Biochemistry 33:2716-2725

39. Sigel RKO, Song B, Sigel H (1997) J Am Chem Soc 119:744755

40. Babcock DF, Hille B (1998) Curr Opin Neurobiol 8:398-404

41. Carafoli E (1979) FEBS Lett 104:1-5

42. Zamzami N, Hirsch T, Dallaporta B, Petit PX, Kroemer G (1997) J Bioenerg Biomembr 29:185-193

43. Davanloo P, Rosenberg AH, Dunn JJ, Studier FW (1984) Proc Natl Acad Sci USA A81:2035-2039

44. Gallo S, Furler M, Sigel RKO (2005) Chimia 59:812-816

45. Jarrell KA, Dietrich RC, Perlman PS (1988) Mol Cell Biol 8:2361-2366

46. Sigel RKO, Sashital DG, Abramovitz DL, Palmer AG III, Butcher SE, Pyle AM (2004) Nat Struct Mol Biol 11:187-192

47. Herschlag D, Cech TR (1990) Biochemistry 29:10172-10180

48. Fedor MJ, Uhlenbeck OC (1992) Biochemistry 31:12042-12054

49. Sigel RKO, Freisinger E, Lippert B (2000) J Biol Inorg Chem 5:287-299

50. Erat MC, Sigel RKO (2007) Inorg Chem 46:11224-11234

51. Mikkola S, Stenman E, Nurmi K, Yousefi-Salakdeh E, Stromberg R, Lonnberg H (1999) J Chem Soc Perkin Trans 2 1619_ 1625

52. Chin K, Pyle AM (1995) RNA 1:391-406 
53. Swisher JF, Su LJ, Brenowitz M, Anderson VE, Pyle AM (2002) J Mol Biol 315:297-310

54. Chu VT, Liu Q, Podar M, Perlman PS, Pyle AM (1998) RNA 4:1186-1202

55. Costa M, Michel F (1995) EMBO J 14:1276-1285

56. Su LHJ, Brenowitz M, Pyle AM (2003) J Mol Biol 334:639-652

57. Qin PZ, Pyle AM (1997) Biochemistry 36:4718-4730

58. Pyle AM (1996) In: Eckstein F, Lilley DMJ (eds) Nucleic acids and molecular biology. Springer, New York, pp 75-107

59. Pyle AM (1996) Met Ions Biol Syst 32:479-519

60. Flynn-Charlebois A, Lee N, Suga H (2001) Biochemistry 40:13623-13632

61. Butcher SE (2001) Curr Opin Struct Biol 11:315-320

62. Doherty EA, Doudna JA (2001) Annu Rev Biophys Biomol Struct 30:457-475

63. Fedor MJ (2002) Curr Opin Struct Biol 12:289-295

64. DeRose VJ (2003) Curr Opin Struct Biol 13:317-324

65. Morrissey SR, Horton TE, DeRose VJ (2000) J Am Chem Soc 122:3473-3481

66. Kim N-K, Murali A, DeRose VJ (2005) J Am Chem Soc 127:14134-14135

67. Babcock DF, Herrington J, Goodwin PC, Park YB, Hille B (1997) J Cell Biol 136:833-844

68. Lehninger AL, Carafoli E, Rossi CS (1967) Adv Enzymol Relat Areas Mol Biol 29:259-320

69. Mccormack JG, Denton RM (1980) Biochem J 190:95-105

70. Gunter TE, Gunter KK, Sheu SS, Gavin CE (1994) Am J Physiol 267:C313-C339

71. Carafoli E (2003) Trends Biochem Sci 28:175-181

72. Saris NE (1963) Scientiarum Fennica Commentationes Physico Mathematicae 28:3-59

73. De Luca M, Engstrom G (1961) Proc Natl Acad Sci USA 47:1744-1747

74. Vasington FD, Murphy JV (1962) J Biol Chem 237:2670-2672

75. Murphy AN, Bredesen DE, Cortopassi G, Wang E, Fiskum G (1996) Proc Natl Acad Sci USA 93:9893-9898

76. Kluck RM, Bossy-Wetzel E, Green DR, Newmeyer DD (1997) Science 275:1132-1136
77. Peebles CL, Perlman PS, Mecklenburg KL, Petrillo ML, Tabor JH, Jarrell KA, Cheng HL (1986) Cell 44:213-223

78. Shannon RD (1976) Acta Crystallogr A 32:751-767

79. Martin RB (1986) Met Ions Biol Syst 20:21-65

80. Morf WE, Simon W (1971) Helv Chim Acta 54:794-810

81. Sigel H, Massoud SS, Corfù NA (1994) J Am Chem Soc 116:2958-2971

82. Sigel H, Griesser R (2005) Chem Soc Rev 34:875-900

83. Moreno-Luque CF, Griesser R, Ochocki J, Sigel H (2001) Z Anorgan Allgem Chem 627:1882-1887

84. Sigel H, Massoud SS, Tribolet R (1988) J Am Chem Soc 110:6857-6865

85. Scheller KH, Abel THJ, Polanyi PE, Wenk PK, Fischer BE, Sigel H (1980) Eur J Biochem 107:455-466

86. Muranyi A, Finn BE (2001) In: Bertini I, Sigel A, Sigel H (eds) Handbook on metalloproteins. Marcel Dekker, New York, pp 93-152

87. Irving HM, Williams RJP (1953) J Chem Soc 3192-3210

88. Grosshans CA, Cech TR (1989) Biochemistry 28:6888-6894

89. Kazakov S, Altman S (1991) Proc Natl Acad Sci USA 88:91939197

90. Giannakis C, Forbes IJ, Zalewski PD (1991) Biochem Biophys Res Commun 181:915-920

91. Stano NM, Chen J, McHenry CS (2006) Nat Struct Mol Biol 13:458-459

92. Sigel RKO, Sigel H (2007) Met Ions Life Sci 2:109-180

93. Travers KJ, Boyd N, Herschlag D (2007) RNA 13:1205-1213

94. Rode BM, Schwenk CF, Hofer TS, Randolf BR (2005) Coord Chem Rev 249:2993-3006

95. Baes CF Jr, Mesmer RE (1976) The hydrolysis of cations. Krieger, Malabar

96. Helm L, Merbach AE (1999) Coord Chem Rev 187:151-181

97. Lincoln SF (2005) Helv Chim Acta 88:523-545

98. Inada Y, Mohammed AM, Loeffler HH, Funahashi S (2005) Helv Chim Acta 88:461-469

99. Lincoln SF, Merbach AE (1995) Adv Inorg Chem 42:1-88

100. Sigel H, Martin RB (1994) Chem Soc Rev 23:83-91 